
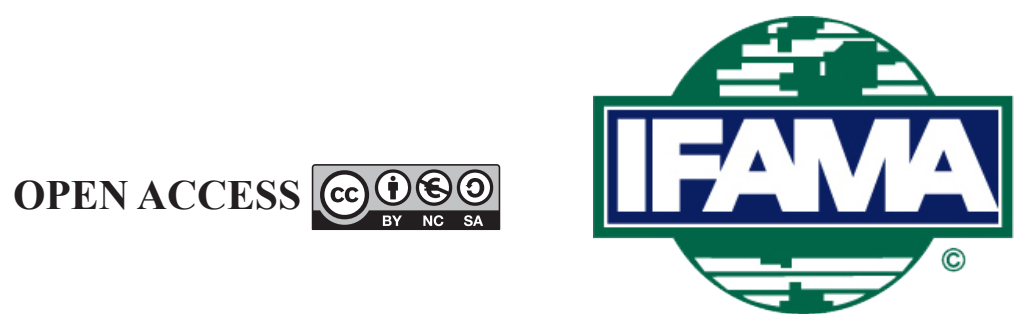

International Food and Agribusiness Management Review

Volume 24, Issue 4, 2021; DOI: 10.22434/IFAMR2020.0053

Received: 16 April 2020 / Accepted: 18 October 2020

Special Issue: Growth of agroholdings and mega-farms in transition and emerging market economies: institutional and organizational aspects

\title{
Propensity for premature filing for judicial financial recovery in large-scale agriculture in Brazil \\ RESEARCH ARTICLE
}

\author{
Antonio Carlos Ortiz ${ }^{\oplus a}$, Henrique Monaco ${ }^{\mathrm{b}}$, Vitor Machado ${ }^{\mathrm{b}}$ and Michael Boehlje $\mathrm{a}^{\mathrm{a}, \mathrm{c}}$ \\ ${ }^{a}$ Senior Associate, Centrec Consulting Group, 3 College Park Ct, Savoy, IL 61874, USA \\ ${ }^{b}$ Graduate Student, Department of Agricultural and Consumer Economics, University \\ of Illinois, 1301 West Gregory Drive, Urbana, IL 61801, USA \\ ${ }^{c}$ Emeritus Distinguished Professor, Department of Agricultural Economics, Purdue \\ University, 1145 Krannert Building, West Lafayette, IN 47907-1145, USA
}

\begin{abstract}
In the Brazilian agricultural space, numerous cases of large farmers have declared themselves in severe financial distress and filed for Judicial Financial Recovery (JFR) in the past few years. Our statistical analysis, although preliminary and based on limited available data, indicates that these operations have shown financial indices at levels that, in general, did not significantly differ from a sample of other larger farmers'. Only 'liquidity' presented a more persistent relationship with the cases of Judicial Recovery. Therefore, it seems that farmers may be resorting to the JFR route prematurely. Within a limited subsample of cases of farmers who filed for JFR, data also shows a pattern with indications that farmers may tend to time their filing to coincide with having their main crops ready for commercialization immediately preceding or after harvesting. This suggests that these farmers might be seeking to free their most recent crop from previous financial and commercial commitments by pursuing a favorable court decision to their JFR. Some factors may be driving this behavior: (1) most farmers in Brazil do not produce a complete set of financial statements on accrual bases, which may lead to errors and incomplete information; (2) not all farmers' debt is registered at the Central Bank, making debt consolidation a challenging discovery process to lenders, who may overleverage clients; (3) farm revenues are concentrated in only a few weeks of the year, allowing farmers that file for Judicial Recovery to carry on with their business, if the courts halt service of previous debt; (4) courts have also allowed these farmers to release assets from collateralized loans. In sum, there may be inaccurate interpretation of the farmers' financial condition due to incomplete information, and a component of moral hazard motivating large farmers filing prematurely for JFR in Brazil. The number and magnitude of these cases may generate negative consequences to agricultural credit costs and availability in the future.
\end{abstract}

Keywords: farmers, financial distress, liquidity, moral hazard JEL code: Q14

(ํ)Corresponding author: carlos.ortiz@centrec.com 


\section{Introduction and literature review}

The segment of larger farmers, including some mega-farmers, has increased considerably in Brazil, as farmers seek for gains of scale and market power, leading to consolidation. Large, entrepreneurial Brazilian farmers have responded to growth in food, feed and energy demands by expanding production and yields considerably during the past decades. According to Senso Agropecuário (Instituto Brasileiro de Geografia e Estatística, 2017), the area utilized by farmers with more than 1000 hectares in Brazil have grown from 150.14 million hectares in 2006 to 167.23 million of hectares in 2017, while number of these large farms grew from 47,000 to 51,000. In 2017 the average size of a farms larger than 1000 hectares was 3,266 hectares. Additionally, average soybean, corn and cotton yields in Brazil have grown by 39.1, 69.6 and 24.2\% respectively from 2006 through 2017 (Conab, 2020).

Until the late 70's, Brazil was a net importer of many food products and received food aid from international institutions (Chaddad, 2016). From then on, a true revolution has swept across the Brazilian farmland, ultimately putting Brazil in a leading supply position in several commodities markets. According to Chaddad (2016), most economists who have studied Brazilian agriculture would agree that this success story is largely due to natural resource availability - in particular, land, water, and favorable tropical climate; public and private investments in agricultural technologies adapted to the tropics; and changes in agricultural policy since the 1970 s towards more entrepreneurial freedom and competition.

Nevertheless, given the size of the country, there is a high degree of heterogeneity in its farming configuration: from a fragmented, cooperative organized and vertically integrated production base in the South; to cane and citrus farmers operating an average area of 74 ha mainly coordinated by processors; to larger scale, independent grain and cotton production in the Mid-West.

Our research involved a data sample of farmers of independently run larger scale operations in the MidWest mainly dedicated to producing grains, oilseeds, cotton, and cattle. This is a region of more recent occupation, in which the agricultural frontiers of the 1990's and early 2000's have led to a higher level of concentration, reaching an average size of 332 hectares per farmer, but counting on thousands of farmers operating thousands of hectares.

While the terms megafarm and agroholdings have not been objectively defined, Hermans et al. (2017) and Chaddad (2016) both include Brazilian cerrado farms of 30,000 hectares in this category. In 2012, according to Chaddad (2016) 38 corporate farms that would fit this category were responsible for the production of 14 million metric tons of oilseeds, which represents roughly $17.1 \%$ of the 82 million metric tons produced in the entire country in that year (USDA, 2013). In this same year, Brazil was responsible for $30.4 \%$ of the global soybean production (USDA, 2013).

The present study has a diverse sample of mainly large farms of an average size of 8,750 ha, but within the range from 240 to 389,000 hectares. Therefore, we will generically use the term 'large farms' throughout this paper and our sample does include some of Brazil's megafarms.

The advent of large farming enterprises in Brazil is not an isolated phenomenon. Hermans et al. (2017) mention how, in the last two decades, we have seen an increasing number of large-scale farm operations, not only in South America, but also in China and in the former Soviet states. This trend has led to a series of academic discussions about the overall structure of these farms and the socioeconomic/environmental consequences and challenges they pose.

In terms of farm enterprise configuration, Chaddad (2016) says that in the Brazilian cerrado, agroholdings are organized in many forms: from public-traded corporations, to privately-held corporations, to familyowned hybrids, known as family groups which retain ownership rights only to family members. This is a broad definition and it does not propose metrics of governance level or structure that would allow a proper qualification of farms of a certain category as agroholdings. 
Miranda and Grandori (2019) use a configurational approach for qualifying agricultural operations by means of size, strategy, organizational and ownership form, and degree of separation between ownership and control. Due to the geographic delineation of the sample utilized in this study and the professional involvement of some of the authors with many of the farmers included in the sample, we can describe it as group of large, family-owned or privately-held corporations, dedicated to growing cash-crops, with no separation between ownership and management.

There are peculiarities in large farming of commodity crops, such as soy, corn and cotton in Brazil that deserve specific consideration:

- Temporal concentration of revenues during a few weeks of the year, enabling the release of significant capital employed in growing the crops from previous financial commitments if judicially supported by a legal case for financial recovery. This allows farmers under Judicial Recovery to carry on their farming activities without the burden of previous debt. The high concentration of production available for sale during a short period of the year differs from many other industries, which tend to have production and sales somewhat distributed throughout the year.

Figure 1 shows cumulative harvesting for soybeans, corn and cotton in the State of Mato Grosso, according to IMEA, representative of the Brazilian Mid-Western harvesting pattern, where most large farmers operate. The curves depict the period of the year in which harvesting and commercial availability of their respective crops occur.

- Farmers operate as individuals, not incorporated as companies, and are not required to generate accounting statements on an accrual basis; they also typically file their income tax based on cash 'in and out' flow. A corporate company instead must generate, file and provide creditors with a complete set of financial statements (income statement, balance sheet and cash flow) on an accrual basis, implying use of double entry for each accounting event, which makes omission and errors naturally explicit.

The current procedure utilized by farmers in which events are captured as single entries on a cash basis make conciliation very difficult and easily inaccurate, thus, not providing enough information for a comprehensive financial analysis. It does not show how capital is being employed and whether there is sufficient free cash flow to support its related debt. The lack of a complete set of financial statements may even let farmers be caught by surprise in case of a liquidity crunch.

- Not all farmers' debt is registered at the Central Bank, and consequent pledges and liens are not centrally registered, making the consolidation of all commitments made by farmers to creditors a challenging discovery process. Moreover, as most farmers do not generate a complete set of accrued financial statements, credit analysis tends to be inaccurate and lead to the extension of credit to already leveraged debtors, accelerating financial distress.

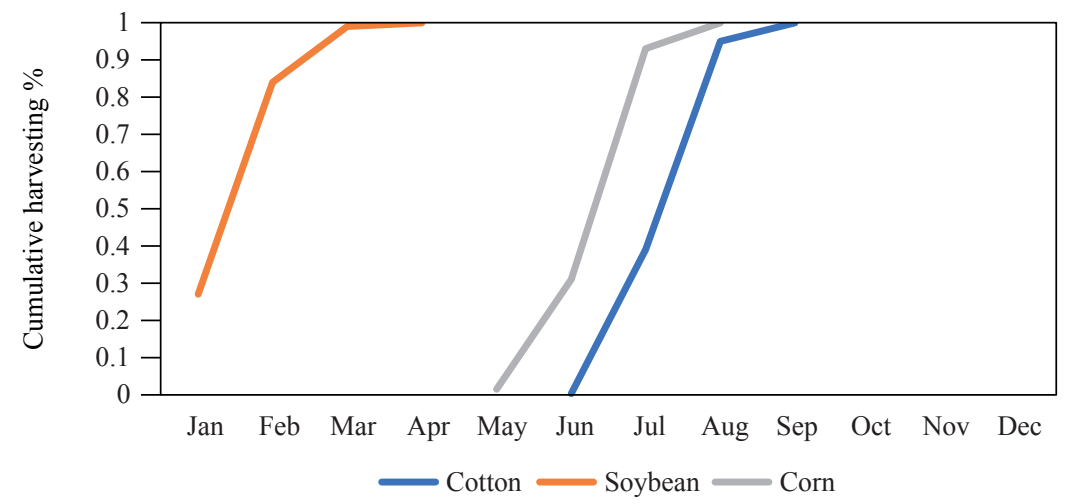

Figure 1. Cumulative harvesting (average 2016-2018) for soybeans, corn and cotton in the State of Mato Grosso, according to IMEA (https://tinyurl.com/yynhr8uu). 
- Courts have recently allowed farmers to free collateral, assets which they had previously committed to creditors, in order to maintain these farmers' production base at its entirety (decision was made by the courts in November of 2019). This decision may incentivize new filings for Judicial Financial Recovery (JFR) and affect the perception of the quality and enforceability of agricultural collateral, with negative consequences to the rural credit supply and its costs in Brazil.

Growth in scale and organizational structure has brought pains to larger farmers, as it has involved more complex financing, management and technology. In the past few years, numerous cases of large farmers have declared themselves in severe financial distress and filed for JFR. These events have become a major topic of discussion among lenders, farmers and policymakers on the possible origins and predictability of these cases.

For the assessment of the financial situation of firms, including farmers, lenders have utilized financial indicators or financial ratios. Several authors have discussed the merits and the composition of financial analysis models, rating and scoring systems as forms of assessing the financial status of a firm and its creditworthiness (Featherstone et al., 2006; Hennins and Sherrick, 2007). According to Turvey (1991), agricultural lenders have increased their attention to credit score models due to many farm failures during the 1990's.

Typically, a quantitative approach to financial analysis utilizes ratios representing solvency, profitability, liquidity, efficiency and repayment capacity (Allcott, 1985; Kohl, 1987; Tongate, 1984). The Basel Accord II (Basel Committee on Banking Supervision, 2003), suggests banks use eight criteria when developing financial and credit risk assessment systems: repayment capacity, solvency, earnings, operating leverage, financial efficiency, liquidity, management, and industry standing.

Data for this study was limited to a few figures and it was possible to assess three indicators: liquidity; solvency and operating leverage. Poor financial ratios might be indicative of financial distress and ultimately of the need for filing for JFR.

Although filing for JFR may be triggered by some degree of financial distress, moral hazard might also be playing a role in some of the cases. In its original form, moral hazard is defined as the effect of insurance coverage on individuals' decisions to undertake activities that may change the likelihood of incurring losses (Nicholson and Snyder, 2012). As Horowitz and Lichtenberg (1993) concluded in a study on insurance, investments and moral hazard, insured farmers may undertake riskier production than do uninsured farmers. Their results suggest that 'insurance exerts considerable influence on corn farmers' chemical use decisions.' Those purchasing insurance applied significantly more nitrogen per acre (19\%), spent more on pesticides (21\%), and treated more acreage with both herbicides and insecticides (7 and 63\%) than did those not purchasing insurance. The authors infer that higher investments in inputs mean undertaking riskier production practices.

Moral hazard has also played a role in debt waivers in India. Worstall (2017) stated that 'if people think that a loan won't have to be repaid then they're really rather likely to take out a loan. Further, if people see those who just cannot repay a loan getting them forgiven then there will be agitation for those who can repay not to have to'. To illustrate his point, he quotes an Indian article: 'The write-off of farm loans in Uttar Pradesh and Maharashtra seems to be encouraging farmers in other states to stop paying back their farm loans to make sure that they will get the benefits of any farm loan waiver program in their state. This has led to a sharp increase in farm loan defaults for Indian banks'. 'In other words, they warned that waivers would encourage farmers to take more and more loans and not pay them back, even when they can, expecting that their liabilities will be waived off.'

Moral hazard in the farming sector may also be present in Brazil as a consequence of a series of government debt waiver programs. Since 2000 there have been twelve of these mandatory debt waiver programs, organized by a series of provisions and laws (Melo and Resende Filho, 2017). 
Melo and Rezende Filho (2017) claim that politically driven processes of rural debt renegotiation induce higher debt levels, moral hazard and adverse selection. By waiving debt, according to these authors, the government creates incentives for riskier borrowers to acquire debt (adverse selection) for riskier projects, and for farmers' intentional default (moral hazard) as they include the possibility of future debt waivers in their decision-making process. Similar conclusions were obtained by Barros et al. (2015) about Brazil's successive debt waivers orchestrated by the government: they have created a culture that affects negatively farmers' commitment to fulfil their financial obligations, especially when creditors were state owned banks.

It is possible that the current legal framework protecting farmers who file for JFR and that the recent court decision of releasing collateral incentivize behavior similar to the series of mandatory debt waivers observed in Brazil's recent past.

The recent frequency and size of the cases filing for Judicial Recovery may also influence lenders' transaction costs, capital availability, lending capacity, and thus loan pricing. The significance of these cases will probably affect banks' perception and statistics on farmers' risk profile, collateral value, loan recovery and losses given default. Consequently, underwriting, capital and pricing policies would have to be reviewed mainly for three reasons.

First, there is a relationship between risk and loan pricing. According to Heffernan (2005), the probability of default derives from information deficiency and from moral hazard. In circumstances of growing uncertainty on the quality of the information provided by farmers and of growing incentives to moral hazard, interest rates would tend to rise whenever borrowers are considered to have a higher risk profile (Campbell, 2007).

Indeed, according to Freitas and Batista (2019), surveyed farmers claimed that interest rates on new loans were one percentage point higher in that year (while the base rate had been declining) as a consequence of the bankruptcy protection decisions by the courts on the various cases of JFR filed by farmers. Campbell (2007) also argued that higher interest rates may lead to further financial distress, therefore making default more likely.

Second, lending capacity depends on capital availability and banks, specifically, are required to provision capital as a direct function of the risk in their portfolio. As risk and losses given default increase, banks are required by their regulators to provision more capital. As capital is a scarce resource, additional capital provisions have a negative effect on lending capacity, reducing credit availability. De Nicolò (2015), found that an increase in lenders' capital ratio by $10 \%$ presented $1.8 \%$ reduction in loan supplies in the long-run. Credit rationing and higher interest rates may contribute to borrowing by riskier farmers and to investments in riskier projects and to more intended default, or moral hazard (Barros et al., 2015; Stiglitz and Weiss, 1981, 1983).

Third, banks may raise their client information requirements, increasing transaction costs and reducing client eligibility, which would affect respectively pricing and access to agricultural credit.

The consequences of these JFR cases affect not only banks and the rural banking industry, but commercial credit provided by input suppliers, traders and processors as well, which is a significant share of financing to Brazil's agriculture. Mano (2019) stated that 'a spate of farmer defaults in Brazil's top grain-producing state is creating headaches for global traders who are among their main creditors and posing challenges to the widespread use of barter in the world's largest soybean exporter.' 


\section{Hypothesis and research questions}

In most cases, large farmers have managed well their increasing scale and complexity, but there have been numerous cases during the past 5 years in which farmers have resorted to filing in court for JFR, which have included freezing debt service, freeing collateral and debt restructuring - often involving substantial debt reduction.

Our hypothesis is that the loose legal requirements coupled with the fact that revenues in agriculture are extremely concentrated in a few weeks create incentives for farmers resorting to going to court in order to restructure - and reduce - debt; free working capital and collateral; and relieve financial distress of even a mild level.

In other words, farmers caught under an increasing level of financial pressure, even if manageable, might resort to premature filing for JFR, given the possibility of keeping a large share of their working capital inflow uncommitted by the season's end, their possibility of freeing assets from foreclosure, and therefore their possibility of carrying on with farming while negotiating debt restructuring with creditors.

In order to verify this hypothesis, we analyzed whether three key financial indices (current assets/current liabilities; total debt/total assets, total debt/EBITDA) from 18 cases which filed for Judicial Recovery differed from a sample of 789 cases of other large farmers in Brazil: i.e. whether selected key financial indices would show a relationship with the propensity of these 18 farmers of actually being in severe financial distress.

Our objective is to provide clarity by means of a conceptual framework and quantitative analysis to assist policy makers, justices and tax authorities in assessing farmers' corporate structure, tax regime, and the JFR's provisions on farming entities.

\section{Data and methods}

The analysis aimed at addressing two questions with respect to farmers that filed for JFR:

- Were their financial indicators worse than the indicators of those who did not file for Judicial Recovery, i.e. were the former in poorer financial condition than the rest of the sample?

- Did they resort to the judicial means right after harvesting their main crop?

\subsection{Question 1}

In order to address the first question, we conducted statistical analysis based on a sample of 806 cases of large farmers in Brazil, of which 18 have filed for JFR during the past four years, whose financial indices were obtained from creditors.

This sample included financial indices of those farmers in three different years. The analysis compared selected financial indices of two groups - farmers who within three years filed for Judicial Recovery; and farmers who have not. Some of the farmers in the overall sample are present in more than one year. The number of points in the sample is therefore slightly larger than the number of farmers. However, we have not included any time or entity effect in the statistical analysis. Famers' identities were not revealed in the sample, but their main crop and their main farming region were identified for a large share of the sample.

Financial data on farmers is extremely limited and we had a limited sample, containing a few figures (all in Brazilian Reais) for the years 2015 through 2017:

- short-term assets;

- short-term liabilities;

- total assets;

- total debt 
- annual revenue;

- annual EBITDA (earnings before interest, tax, depreciation and amortization).

This set of basic information allowed us to calculate usual financial ratios as explanatory variables:

- Liquidity was calculated as short-term assets divided by short-term liabilities, which was included to represent the ability to fulfil short-term financial obligations.

- Balance sheet leverage, or asset leverage, was calculated as total debt over total assets, which was included as a measure of solvency.

- Operating leverage was represented by total debt over EBITDA (earnings before interest, taxes, depreciation, and amortization), included as a measure of debt relative to income.

We also included in the analysis the absolute value of farmers' annual revenues to control for size. And finally, as part of the set statistically analyzed, we have a dummy variable to indicate whether the case involved JFR or not.

In magnitude, annual revenues of the group that had filed for Judicial Recovery was similar to the group that had not (BRL 53.72 million vs 60.97 million in 2016; BRL 70.58 vs 70.79 million in 2017; and BRL 83.11 million vs 73.07 million in 2018). As a reference, if we consider the annual revenue of a soybean and corn producer as BRL 7,800/hectare (IMEA), the sample's estimated average farmer size would be equivalent to 8,750 hectares.

Liquidity refers to the firm's capacity to generate sufficient cash to meet its financial commitments as they become due, while solvency is related to the firm's ability to meet total claims (Barry and Ellinger, 2012). Operating leverage reflects the proportion of debt to operating income.

The data was analyzed based on the average marginal effect (AME) of the explanatory variables of a crosssectional logistic regression model (logit). The response or dependent variable was the existence of severe financial distress representing the need for filing for JFR. The explanatory variables were liquidity (CR), asset leverage (DA), operating leverage (DEBITDA) and annual revenue (FAT). As lack of liquidity and high leverage would be indicators of financial fragility and propensity for financial distress, we would expect that these variables would present a strong relationship with the cases of JFR; liquidity would present a negative relationship; and both leverage indicators would present a positive relationship.

The model is represented by:

$$
Y_{i t}=\beta_{0}+X \beta_{i t}+\varepsilon_{i t}
$$

where $\mathrm{i}$ and $\mathrm{t}$ represent the company and the time; $\mathrm{Y}$ is a categorical variable indicating the propensity of severe financial distress, representing the need for filing for JFR; $\beta$ is the matrix of explanatory variables; $\varepsilon$ is the idiosyncratic error.

\subsection{Question 2}

In order to address the second question, the 18 cases that filed for Judicial Recovery were plotted on a timeline according to the month of their filing and compared with a curve representing the usual harvesting and commercial availability of the crop during the year.

The dates of court filing were obtained in the courts' documents. The crop harvesting and commercial availability period was based on data informed for the State of Mato Grosso, by the Instituto Matogrossense de Economia Agropecuaria ${ }^{1}$, to represent the harvesting season as it occurs in the Brazilian Mid-West for

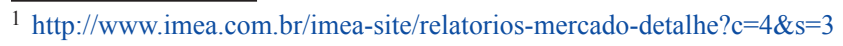


lack of broader regional statistics. We would expect that farmers would time their filings for JFR immediately before or after harvesting their main crop.

\section{Main results}

\subsection{Statistical model for analyzing selected financial indices and their relationship with cases of Judicial Financial Recovery}

As depicted in Table 1, balance sheet leverage, represented by debt/assets did not show any statistical relationship with the cases of Judicial Recovery in any year, indicating that in the years previous to filing, the level of solvency of the firms that filed for Judicial Recovery did not differ from those who did not file for Judicial Recovery.

Only in the 2018's sample did operating leverage, measured as debt/EBITDA, presented statistical significance at $P<0.1$ (not at $P<0.05$ ) with respect to cases of Judicial Recovery, indicating that operating leverage could be an indicator of propensity for Judicial Recovery. But this statement cannot be corroborated by the results of the remaining sample, for which operating leverage did not show any statistical relationship with the cases of Judicial Recovery.

Annual revenue, or size of operation, did not present a statistical relationship with the cases of Judicial Recovery in any year.

Only liquidity, represented by current ratio, or current assets/current liabilities, presented a more persistent relationship with the cases of Judicial Recovery, i.e. lower liquidity ratios would have increased the propensity of filing for Judicial Recovery in two out of the three years tested. However, that did not occur in 2018 and not if we combine data for all three years.

Table 1. Summary of the results.

\begin{tabular}{lcl}
\hline Explanatory variables & Coefficient & $\boldsymbol{P > | \mathbf { z } | ^ { 1 }}$ \\
\hline 2016 & & \\
Liquidity: current assets / current liabilities & -0.0695 & $0.0673^{*}$ \\
Balance sheet leverage: debt / assets & 0.0967 & 0.1233 \\
Operating leverage: total debt / EBITDA & 0.0008 & 0.3014 \\
Annual revenue & -0.0001 & 0.5460 \\
2017 & & \\
Liquidity: current assets / current liabilities & -0.1607 & $0.0159^{* *}$ \\
Balance sheet leverage: debt / assets & -0.0056 & 0.9441 \\
Operating leverage: total debt / EBITDA & 0.0001 & 0.9861 \\
Annual revenue & 0.0000 & 0.7791 \\
2018 & & \\
Liquidity: current assets / current liabilities & 0.0087 & 0.4724 \\
Balance sheet leverage: debt / assets & -0.0076 & 0.8575 \\
Operating leverage: total debt / EBITDA & 0.0011 & $0.0768^{*}$ \\
Annual Revenue & 0.0000 & 0.9247 \\
\hline
\end{tabular}

$1 *$ significant at 0.1 level; ** significant at 0.05 level. 


\subsection{Analysis of the time distribution of the cases of Judicial Financial Recovery and its relationship with the crop cycle}

There has been some indication that farmers may be timing their filings for JFR to occur during the months immediately preceding or immediately succeeding their respective main crop harvesting (either soy or cotton) as illustrated by Figure 2.

Corn tends to be the second most important crop when soybean is the main crop, which may be explaining a distribution of filings of soy farmers during the corn harvesting season. There is in the sample only one case of a cotton farmer who filed for Judicial Recovery during the main crop's season (April). The harvesting period analyzed and depicted in Figure 2 represents the cumulative proportion of harvested crops in the State of Mato Grosso as indicative of a typical pattern of the Brazilian Mid-West. Only data for Mato Grosso is available and it was used as a representation of the Mid-Western pattern because there is no aggregated data for the entire region. Not all farmers in the sample analyzed are in Mato-Grosso, but they were all in the Mid-West. Mato Grosso has the largest share of the region's production.

The number of data points was very limited for this analysis, but the pattern of filings for JFR throughout the crop seasons seems to indeed suggest the notion that farmers tend to time these filings to occur during periods of the crop cycle in which they are able to hoard more cash by freeing production ready to be sold from previous financial and commercial commitments, and may be indicative of moral hazard behavior.

\section{Discussion}

These results must be viewed as an exploratory first step, as the data utilized present several limitations, either due to the size of the subsample of cases under JFR, or to the quality and variety of financial figures provided in the overall sample. The difficulty of obtaining comprehensive and accurate financials for the analysis generated several weaknesses in this study. Although the overall sample was relatively large, farmers' financial reports are neither produced on an accrual basis, nor audited, which makes them naturally prone to inaccuracy. The number of cases in our subsample of Judicial Recovery cases during the period analyzed was small, thus subject to the presence of outliers and statistical inaccuracy.

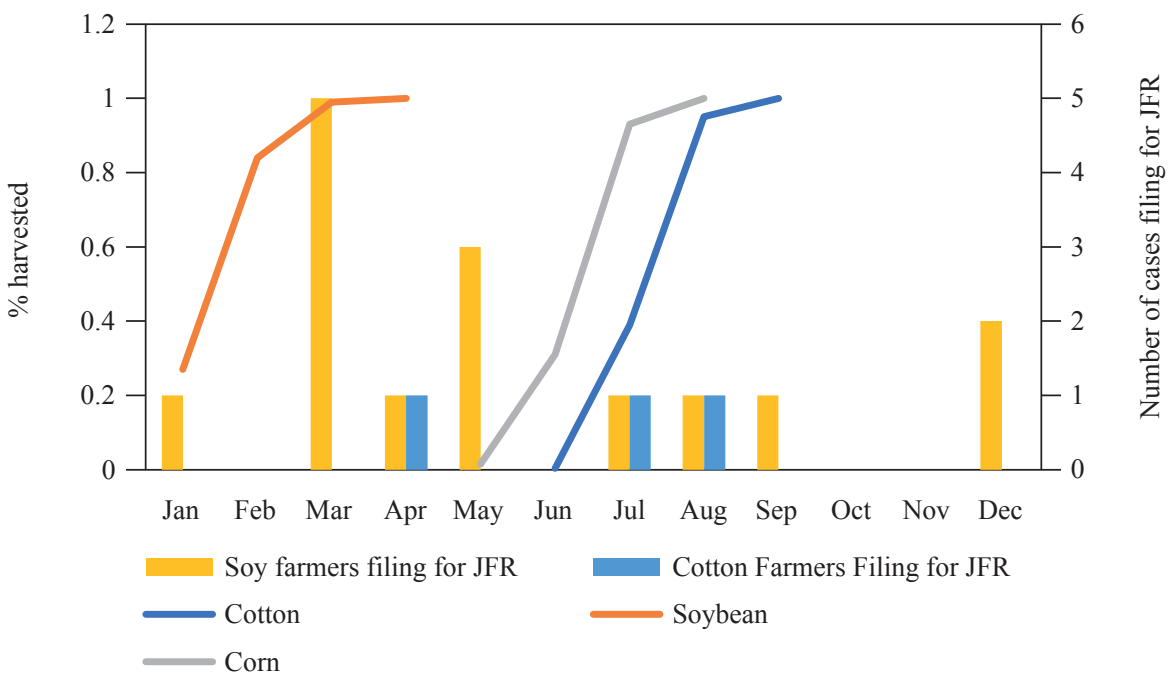

Figure 2. Number of filings for Judicial Recovery across the calendar year vs 2016 to 2018 average percentage harvested of soybeans, corn and cotton in the State of Mato Grosso, according to data published by IMEA (https://tinyurl.com/yynhr8uu). 
The statistical analysis showed a weak relationship between the level of selected financial indices and the propensity for filing for JFR. Only some of the indicators (liquidity and operating leverage), in some of the years analyzed, have shown significant relationships with respect to filing for Judicial Recovery, i.e. indicating that these farmers might be facing some degree of financial distress. A conclusion that must be taken with caution, considering that according to Barry and Ellinger (2012), no isolated measure can describe the financial performance of a business in a dynamic environment and to properly access a firm's financial condition one must analyze a set of indices.

The signals shown in the results of the statistically significant relationship between the explanatory variables and the independent variable were as expected: 'liquidity' shows a negative relationship with financial distress (filing for JFR), while 'operating leverage' shows a positive relationship with financial distress (filing for JFR).

A second element analyzed was the timing of the filings for recovery in court. The subsample of farmers who filed for JFR was very limited, but the pattern seems to suggest that these filings have in general coincided with the period in which these farmers had their main crops either mature or ready for the market. At this point in the crop cycle, most of the farmers in this subsample resorted to a Judicial Recovery process, which have allowed these farmers to free collateral and pre-sales contracts respectively from previous financial and commercial commitments.

The results of our analysis are only very preliminary and based on a limited number of cases within a sample of farmers presenting a limited number of financial figures. But they suggest that there is potential for further studies to investigate farmers propensity to prematurely file for JFR to protect their assets and cash flow either due to lack of preparedness, or even due to moral hazard. Given the importance of Brazil's large farming agriculture and the impact that continuing cases of JFR would have in its food and agribusiness chains, it is worth pursuing further analysis.

\section{Concluding remarks}

Considering that Brazilian farmers are exempted from preparing accounting statements on an accrual basis, they tend to have incomplete financial information on their operation due to the natural shortcomings of financial reports being prepared on a cash basis. Because of the potential inaccuracy in the representation of farmers financial condition and of their true risk level, lenders, policy makers and the farmers themselves might be operating in a misinformed environment prone to judgment errors. It is possible that farmers, not fully understanding their financial position, while encountering some level of cash flow or refinancing challenges, are encouraged to pre-emptively file for JFR.

The results of our analysis, although very preliminary and limited, suggest that there is potential for further studies to explore a more comprehensive universe of cases in order to investigate farmers propensity to prematurely file for JFR, either to protect their assets and cash flow in deep distress, or due to lack of preparedness.

Additionally, further research should consider that the literature suggests moral hazard may also influence farmers' financial decisions due to successive government sponsored debt waiver programs and to favorable court decisions accepting these recovery requests, which have included releasing collateral.

JFR cases and their legal outcome may over time generate negative consequences to the rural credit market in Brazil, as these cases influence the statistics used by lenders to model the probability of default and losses given default of their agricultural portfolio. Recent court decisions releasing collateral under the umbrella of JFR may weaken the assumptions on collateral value upon which banks' capital, loan qualification and pricing policies have been based. These assumptions may have to be revised by banks and the regulator. 
Additional further questions to be explored based on this preliminary research would be the consequences of farmers filing for JFR to lenders' policies, and to the cost and volume of rural credit in Brazil, whether they increase systemic risk, whether they have involved moral hazard and whether they have reduced the value of collateral.

\section{References}

Allcott, K.W. 1985. An agricultural loan rating system. The Journal of Commercial Bank Lending 65: 29-38. Barros, E.S., L.F. Xavier, D.T. Pessoa and T.F. Sobel. 2015. Endividamento Agrícola: Quão Comprometidos são os Produtores do Polo Petrolina-Juazeiro Frente a Suas Dividas? Economia Aplicada 19(1): 171-200. https://doi.org/10.1590/1413-8050/ea128281

Barry, P. and P.N. Ellinger. 2012. Financial management in agriculture. Pearson, London, UK.

Basel Committee on Banking Supervision. 2003. The New Basel Capital Accord. Committee on Banking Supervision, Basel, Switzerland. Available at: https://www.bis.org/bcbs/bcbscp3.htm

Campbell, A. 2007. Bank insolvency and the problem of nonperforming loans. Journal of Banking Regulation 9: 25-45.

Chaddad, F. 2016. The economics and organization of Brazilian agriculture. Elsevier USA, Frisco, CO, USA. Companhia Nacional do Abastecimento (Conab). 2020. Série histórica das safras: Grãos - por produto. Available at: https://www.conab.gov.br/info-agro/safras/serie-historica-das-safras/item/ download/33671_384e5d8b1ce6f6bb878cd92b7d2ef3df

De Nicolo, G. 2015. Revisiting the impact of bank capital requirements on lending and real activity. SSRN: 1-37. https://doi.org/10.2139/ssrn.2688110

Featherstone, A.M., L.M. Roessler, and P.J. Barry. 2006. Determining the probability of default risk-rating class for loans in the seventh farm credit district portfolio. Review of Agricultural Economics 28(1): 4-23.

Freitas, T. and F. Batista. 2019. Brazilian farmers pay the price of protecting insolvent growers. Bloomberg, November 26. Available at: https://www.bloomberg.com/news/articles/2019-11-26/brazilian-farmerspay-the-price-of-protecting-insolvent-growers

Heffernan, S. 2005. Modern banking. Wiley, Chichester, UK.

Hennings, E. and B.J. Sherrick. 2007. Measuring the credit risk of AgriBank loans under the new Basel capital accord: a logit regression approach. In: American Agricultural Economics Association Annual Meeting. July 29- August 1, 2007. Portland, OR, USA. https://doi.org/10.22004/ag.econ.9987

Hermans, F.L.P., F. Chaddad, T. Gagalyuk, S. Senesi and A. Balmann. 2017. The emergence and proliferation of agroholdings and megafarms in a global context. International Food and Agribusiness Management Review 20(2): 175-186. https://doi.org/10.22434/IFAMR2016.0173

Horowitz, J.K. and E. Lichtenberg. 1993. Insurance, moral hazard, and chemical use in agriculture. American Journal of Agricultural Economics 75(4): 926-935. https://doi.org/10.2307/1243980

Instituto Brasileiro de Geografia e Estatística. 2017. Censo Agropecuário 2017. IBGE, Rio de Janeiro, RJ, Brasil. Available at: https://biblioteca.ibge.gov.br/visualizacao/periodicos/3096/agro_2017_ resultados_definitivos.pdf

Kohl, D.M. 1987. Credit analysis scorecard. Journal of Agricultural Lending 1: 14-22.

Mano, A. 2019. Brazil farmer defaults bur soy traders betting on barter. Reuters, May 21. Available at: https:// www.reuters.com/article/us-brazil-agriculture-bankruptcy-analysi/brazil-farmer-defaults-burn-soytraders-betting-on-barter-idUSKCN1SR284

Melo, L.B. and M.A. Resende Filho. 2017. Determinantes do Risco de Crédito Rural no Brasil: Uma Crítica às Renegociações da Dívida Rural. Revista Brasileira de Economia 71(1): 67-91.

Miranda, B.V. and A. Grandori. 2020. Structural heterogeneity in farm structures: a configurational approach. Journal of Agribusiness in Developing and Emerging Economies 10(1): 65-83. https://doi.org/10.1108/ JADEE-12-2018-0183

Nicholson, W. and C.M. Snyder. 2012. Microeconomic theory: basic principles and extensions. Cengage, Boston, MA, USA.

Stiglitz, J.E. and A. Weiss. 1981. Credit rationing in markets with imperfect information. The American Economic Review 71(3): 393-410. 
Stiglitz, J.E. and A. Weiss. 1983. Incentive effects of terminations: applications to the credit and labour markets. The American Economic Review 73(5): 912-927.

Tongate, R.E. 1984. Risk indexing: a valuable tool for today's lender. Agricultural Finance, March: 12-13

Turvey, C.G. 1991. Credit scoring for agricultural loans: a review with applications. Agricultural Finance Review 51: 43-54.

USDA Foreign Agricultural Service. 2013. Oilseed: world markets and trade. USDA, Washington DC, USA. Available at: https://downloads.usda.library.cornell.edu/usda-esmis/files/ tx31qh68h/2514nk855/6395w7441/oilseed-trade-12-10-2013.pdf

Worstall, T. 2017. Moral hazard and the writing off of Indian farm loans. Forbes, August 16. Available at: https://www.forbes.com/sites/timworstall/2017/08/16/moral-hazard-and-the-writing-off-of-indianfarm-loans/\#76061ba35d76 